\title{
Who is Relocating Whom in the Renovation of Shanghai's Old City?
}

\section{Zhang Kai}

Translator. Will Thornely

\section{(2) OpenEdition}

\section{Electronic version}

URL: http://journals.openedition.org/chinaperspectives/6102

DOI: 10.4000/chinaperspectives.6102

ISSN: 1996-4617

\section{Publisher}

Centre d'étude français sur la Chine contemporaine

\section{Printed version}

Date of publication: 15 March 2013

Number of pages: 29-39

ISSN: 2070-3449

\section{Electronic reference}

Zhang Kai, «Who is Relocating Whom in the Renovation of Shanghai's Old City? », China Perspectives

[Online], 2013/1 | 2013, Online since 01 March 2016, connection on 28 October 2019. URL : http:// journals.openedition.org/chinaperspectives/6102; DOI : 10.4000/chinaperspectives.6102 


\title{
Who is Relocating Whom in the
}

\section{Renovation of Shanghai's Old City?}

\author{
ZHANG KAI
}

\begin{abstract}
The aim of this article is to describe the various actors who intervene in the renovation (and therefore relocation) projects that have been proliferating in Chinese cities for several years. The term "relocation" is a translation of the French term "délogement," which was coined by the author to refer to the specific process that brings together urban renovation, destruction of housing, and displacement of occupants in China today. Based on a field study conducted in Shanghai between 2003 and 2008, this paper intends to reveal the diversity of actors involved in such projects and the varied relationships they maintain with the official sphere, which directly influences the course of negotiations regarding compensation and rehousing.
\end{abstract}

KEYWORDS: Shanghai, urbanisation, renovation, relocation.

$\mathrm{T}$ he aim of this article is to identify the various actors present during the relocation processes brought about by urban renovation projects, and to analyse how they interact and the ambitions that sustain them. ${ }^{(1)}$ More specifically, it hopes to contribute to a better understanding of these processes by describing the many actors whom residents come up against in such circumstances, and their respective responsibilities. It is based on the observation of two specific renovation projects launched in 2003 in the Old City of Shanghai, by a public developer in one case and by a private developer in the other. (2)

It is helpful to start with a brief look at the situation in the two districts studied. The so-called Xiangyuan Lu renovation project, which was entrusted to the public developer Fuyue in Shanghai, took place between 2003 and 2007 and resulted in the relocation of all the occupants (4,000 households) living on the seven hectares in question. The so-called Gujia Lu project, which was entrusted to the private developer Zheshang, took place between 2003 and 2005 and led to the relocation of only 800 households, representing 26 percent of the local population, before it was forced to stop due to a lack of capital. (3)

It should be pointed out that the decision to start a renovation project in the Old City of Shanghai is the responsibility of the District government, which draws up an annual renovation plan and then turns to different developers depending on the nature of the projects. The choice of developer is governed by a variety of motivations. Either the District government directly approaches an experienced and powerful public developer, due to the specific difficulty or social consequences of the project, or it launches a call for tenders, in particular when the projects call for a major contribution from the market.

Once the District government and the developer have signed a land use contract, the relocation of the affected occupants and work units begins. Building permits and plans pertaining to "protected historic districts" (4) are actually required to comply with regulations far stricter than those covering ordinary land and must be approved - in what can be a fairly long process - by the Town Planning Bureau of the municipality of Shanghai. Anxious to be able to start construction as early as possible, property companies do everything in their power to obtain building permits just before the end of the relocation phase.

Insofar as land is scarce in the city centre, renovation projects generally aim to radically transform the property landscape and therefore to relocate

1. This article is taken from a doctoral thesis entitled Droit au délogement et protection du patrimoine:Xianyuan Lu et Gujia Lu, deux projets de rénovation dans la vieille ville de Shanghai (Right of relocation and protection of cultural heritage: Xiangyuan Lu and Gujia Lu, two projects of renovation of the Old City of Shanghai), defended in April 2010 at the École des Hautes Études en Sciences Sociales (School for Advanced Studies in the Social Sciences). As a town planner, I had access to the plans and documents for these renovation projects. However, the investigation is essentially based on observation work carried out between 2003 and 2008 in the two districts in question and on interviews conducted with the various actors involved in the observed relocation processes. In addition to this, I completed an assignement of several months as a town planner in one of the Residents' Committees.

2. Urban renovation is radically changing the face of the old districts of Shanghai. Between 1991 and 2000, 3.65 million square metres (construction surface area) of old housing was destroyed. In 2001, Shanghai City Hall designated a new phase in its urban renovation programme, this one concerning more than 100 million square feet of old housing. There is a very extensive bibliography of the city of Shanghai in Chinese, English, and French. As a full bibliography is available in my thesis, I will restrict myself here to citing the following works: Marie-Claire Bergère, Histoire de Shanghai, Paris, Fayard, 2002; Françoise Ged, Shanghai, habitat et structure urbaine, 1842-1995, Paris, EHESS, 1997 (thesis); Valérie Laurans, "Shanghai: Modern Conveniences as an Argument for Displacing Residents," China Perspectives, No. 58, March-April 2005, pp. 10-21.

3. The sometimes violent conflicts, at times also involving illegal actions, caused by relocations in many urban centres are well known. I did not observe any such episodes during the investigation, and the factors that explain why this type of escalation may or may not occur, even though the ingredients are often very similar from one district to another, are little known. Nor did I have the opportunity to observe the legal proceedings undertaken by certain occupants. However, I would like to emphasise that the stoppage of one of the two observed projects resulted from the very high compensation claimed by the occupants, which had not been foreseen by the developer. For further reading on the forms of urbanisation observed in China and the problems to which they give rise, the following are recommended:You-Tien Hsing, The Great Urban Transformation: Politics of Land and Property in China, Oxford, Oxford University Press, 2010; and Eva Pils, "Waste No Land: Property, Dignity and Growth in Urbanizing China," Asia-Pacific Law \& Policy Journal, Vol. 11, No. 2, 2010, Pp. 1-48. For the purpose of confidentiality, the names of the property developers have been changed.

4. According to Article 8, Chapter 2 of the "Plan to protect the historic districts and buildings of Shanghai," which was passed by the People's Congress of Shanghai in July 2002, districts where there is a concentration of buildings whose style, spatial layout, and overall landscape represent a typical culture from a certain age can be considered to be "protected historic districts." Up until August 2008, the government of Shanghai had approved the creation of 44 protected historic districts, 12 of which are located in the city centre, covering an area of 27 sq kilometres, and 32 of which are in the suburbs, covering an area of 14 sq kilometres. 
the entire population that lives there. For a short period in the late 1990s, the principle of rehousing relocated occupants locally prevailed in the city central of Shanghai. However, in order to achieve an economic balance and enable developers to make higher profits, this principle was very soon abandoned and replaced either by rehousing the occupants in a district much further from the centre or by paying them monetary compensation. Local rehousing sometimes prevails today in small and medium-sized cities, for example in Fujian and Zhejiang provinces, where occupants are more capable of engaging in a successful power struggle with private promoters. In a large city such as Shanghai, it is much harder for occupants to make their voices heard.

Therefore, at the start of a relocation process, an agreement is signed between a District government and a developer; in theory, the latter then becomes the project manager of this process.

\section{The various actors who intervene in a relocation project}

When relocation projects are discussed in the academic litterature, the resistance of certain occupants is often described without any clear knowledge of the identity of the people the inhabitants are directly or indirectly resisting. Similarly, the nature of the links established between the two parties remains blurred: do these interactions fall within the commercial field or that of administrative relationships? Are they exclusively economic in nature, or are they also political?

To get straight to the point, a large number of actors intervene in projects of this kind: the District government, the developer, whether public or private, the relocation management centre, the relocation company, the Residents' Committee, and finally, the residents themselves (the Chinese terms are provided in the relevant sections below).

\section{The District government}

It is no coincidence that this actor should be covered first, since all the interactions between the various parties, and in particular any negotiations, take place in the shadow of the District government. This is true not only in Shanghai but in other Chinese cities as well.

It should first be noted that a so-called "two-tier government" (liangji zhengfu 两级政府) method of urban management prevails in Shanghai. According to document number 111 adopted in 2001, "The Property and Real Estate Management Bureau of the district is responsible for controlling the relocation processes in the territory it administers, and does so under the management of the Municipal Bureau" (article 6). The "Property and Real Estate Management Bureau of the district can neither carry out the relocation itself, nor have it carried out by delegation" (article 17).

The District government (qu zhengfu 区政府) therefore draws up the renovation plan for the old districts and gives its political support to the relocation operations that result from it. Although it does not directly finance them itself, the fact that it provides such official support, which is then relayed in practical terms by the Subdistrict Offices and Residents' Committees, exerts a direct influence on the success of these projects. Therefore, during the course of the negotiations conducted between the relocation company and households, which can be thought of as a form of psychological warfare, the former, thanks to the explicit support it receives from the Subdistrict Offices and Residents' Committees, has access to all the in-

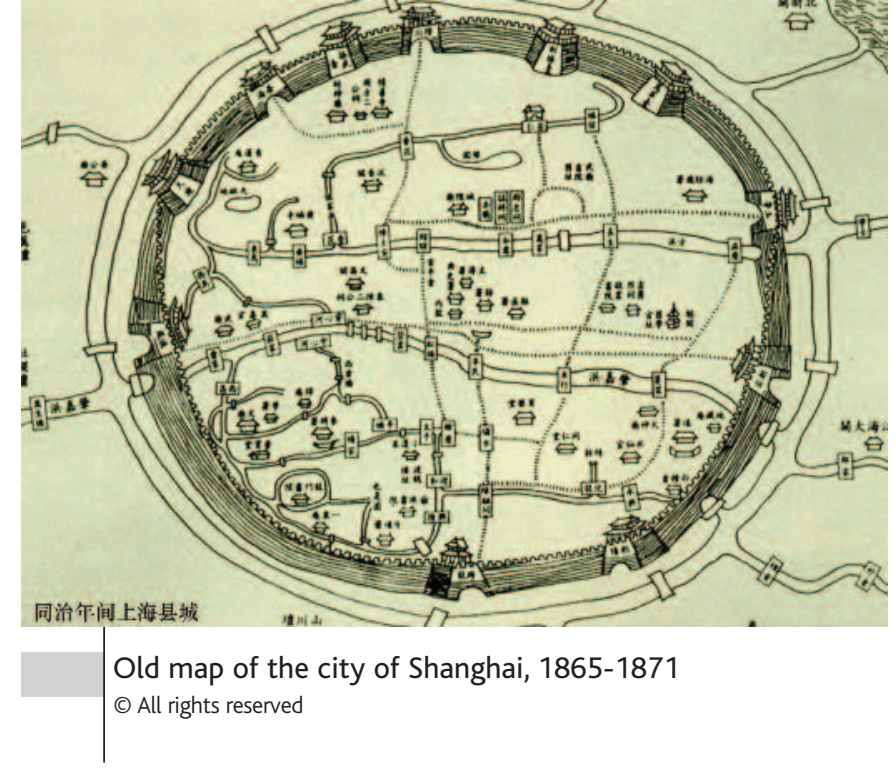

formation it requires concerning the situation of the occupants, while the latter receive only fragmentary information on the process underway. Moreover, the relocation company can reveal to all and sundry the consent given by the local authorities, not only to the renovation project but also to the relocation process that results from it, thus instigating, from the outset, a power struggle with residents that it is always likely to win, because opposing the relocation company and the other actors involved in this process also means opposing the District government.

"Ten words spoken by the contractor of the relocation company do not equal one word spoken by a member of the Residents' Committee. Without the participation of the executive members of the Party who were in the Residents' Committee, relocation for the World Expo would never have been so easy," acknowledges Zhai Juan, deputy secretary of the Party Committee in the Pudong relocation company, which took part in the relocation process for the 2010 World Expo in Shanghai. (5) This all explains why, even though the official role of the District government has now shifted from one in which it carries out relocations to one in which it merely supervises them, occupants still consider these operations to be government business and feel that the role of the relocation company is simply to carry out its decisions. Even in the case of a project involving a private developer such as the Zheshang company, the occupants remain convinced that while it is the developer who takes centre stage, the relocation process is actually being carried out by the District government behind the scenes.

Although the district and city governments are supposed to carry out renovation and urbanisation projects as guarantors of the public interest, in reality, these projects must achieve a financial balance and therefore need to attract investors and guarantee them profits. In order to speed up the renovation of the old districts of Shanghai, the departments responsible for urbanisation matters therefore take into account the profits that can be generated for developers. For example, in the case of the two projects that concern us, the land use rights were transferred at a time when a plan to protect the Old City of Shanghai was being put in place to actually restrict the density of the population that could be housed in the renovated districts. Despite this, the developers won the right to build for a population

5. Du Jiong (ed.), Fasheng zai Pudong shibo dadongqian de baige gushi (A hundred stories of rehousing in Pudong District for the 2010 World Expo in Shanghai), Shanghai, Shanghai kexue jishu chubanshe, 2006 
density far higher than that provided for in this text. The district and city governments thus avoided having to pay the developers the high levels of compensation to which they would have been entitled had they suddenly been required to comply with the new legislation. In other words, they preferred to sacrifice the public interest and protect that of the developers. This choice reveals the lack of control brought to bear today on the implementation of urbanisation policies. Similarly, in order to hasten the completion of these projects, the criteria concerning the number of old dwellings that had to be spared from destruction were considerably diluted, resulting in a level of 10 percent being set in a district whose historic character should officially have been preserved in its entirety. It should be acknowledged that significant progress is nonetheless represented by the fact that district and city urbanisation departments can finally point to official measures that designate old districts for protection where there were previously no such rules in place, and protect at least a proportion of the buildings.

\section{The property developer}

The commercialisation of real estate and property, the end of the housing allocation system, and the introduction of a system providing compensation following relocations are all changes that have taken place within a period of around ten years at the end of the twentieth century and the beginning of the twenty-first century. The government has withdrawn from its role as project manager in the renovation of old districts. Property developers (kaifa shang 开发商), by obtaining permits to build, contractually, from the District governments, have become the kingpins of the process of renovating old districts and are therefore, in theory, the most important actors in relocations.

As far as the relocation process and the means used to carry it out are concerned, there is no fundamental difference between public companies and private companies. Similarly, the process in an old district of the city is not fundamentally different from that on more ordinary land. In each case, the developer raises funds for the relocation, identifies the dwellings to be earmarked for rehousing, and draws up the relocation plan. The negotiations with each household are then entrusted to a relocation company with whom the developer has signed a contract.

Private and public developers alike obey market logic, and it would be futile to expect a public developer to show greater concern for the public interest. Insofar as no public funds are available for the renovation of Shanghai's old districts, and insofar as there are no real regulations aimed at safeguarding the common good, district and city governments are quite happy to turn to property developers and offer them very favourable conditions to carry out these renovation projects.

However, the links between the developers and the District government vary according to whether the developers are private or public. Public companies are financed by state capital, and the understanding between them and the municipal government is self-evident. Their alliance is close and strong, as it is largely shielded from transformations in society, market fluctuations, and changes in political personnel that occur when certain mandates are renewed. The municipal government often turns to large public companies when the projects in question can generate significant profits. In exchange, the municipal government asks these companies to help it achieve its aims. Thus, in first approaching Fuyue about the projects to renovate the Old City, the government expected this company to help solve the question of rehousing the occupants of the Old City, who were both poor and numerous, whilst also attracting capital. In the case of renovation

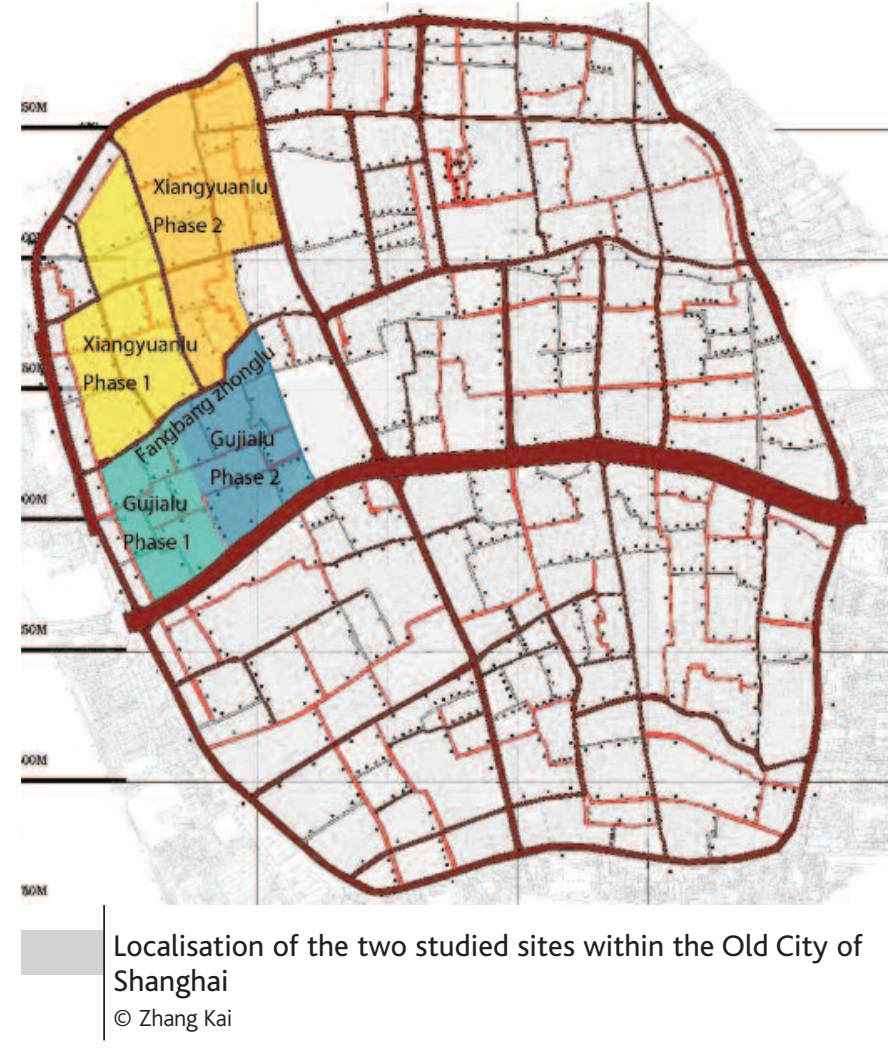

projects in the old districts, the municipal government does not allocate capital to public companies, instead giving them other advantages, such as guaranteeing bank loans. Conversely, although public companies operate in the same way as ordinary companies, generating profit is not their primary objective: they are expected, first and foremost, to help the government realise its political goals. Should they ever meet with financial setbacks as a result of certain projects, the municipal government compensates by granting them profitable opportunities elsewhere.

Private companies do not have the same obligations to the municipal government as public developers, and their aim is clear: profitability. For this purpose, they need to establish good relations with the local government in order to be informed of its projects, to be approached for some of them, and to reduce the uncertainties accompanying it. It is, of course, necessary to clarify that "compared to Western society, Chinese society is not built on people or on the idea of society, but on interpersonal relationships [guanxi 关系]." "(6) "For the Chinese, the logical process of actions established by one or more individuals is: personal action; interpersonal action; team or group action." (7)

In a society in which interpersonal relationships are considered highly important, the ability of private companies to acquire resources with the help of the "guanxi" they possess and nurture constitutes a kind of "social capital." "(8) Acquiring and making use of this social capital represents knowledge

6. Qin Haixia, "Guanxi wangluo de jiangou: Siying qiyezhu de xingdong luoji" (Construction of social networks: The logic of action of the contractor), Shehui, No. 5, 2006, pp. 3-21.

7. Wang Hejian, "Ziwo xingdong de luoji: Lijie 'xin chuantong zhuyi' yu Zhongguo danwei zuzhi de zhenshi de shehui jiangou" (The logic of action of the self:Understanding neo-traditionalism and current social training of the Chinese "Work Unit"), Shehui, No. 3, 2006, pp. 13-22.

8. According to Pierre Bourdieu, social capital is the sum of all the resources (financial capital as well as information, etc.) mobilised through a more or less extensive and mobilisable network of relationships that brings a competitive advantage by ensuring that investments enjoy higher profit levels. Dominated companies can use their social capital to apply pressure on the state in order that it changes the game in their favour. See Pierre Bourdieu, The Social Structures of the Economy, Polity, 2005. 
that is irreplaceable when it comes to increasing the company's opportunities and income. Of the relationships that need to be developed, those established with the various levels of government are indisputably the most important in order to gain access to public resources. Therefore, most prosperous private contractors in China have close, stable relationships with the state employees in various government departments. It is a generally accepted principle that substantial amounts must be paid out to maintain these relationships, which will, in return, allow them to defend and consolidate their relationships over the long term.

By participating in the renovation project in the Old City of Shanghai, the private company Zheshang aimed not only to obtain economic gain, but also to establish its political ascendancy by strengthening its ties with the municipal government. Before turning to property construction, this company was involved in the electric cable industry. Having accumulated profits, it turned to more political objectives. It therefore invested in education, setting up the "Golden Apple Bilingual School" in order to foster favourable public opinion. Its managing director became a representative in the People's Congress of the municipality of Shanghai, as well as vice-president of the Industrial and Commercial Committee in Shanghai. He was also named a "model worker" (laomo 劳模) at the national level. The efforts deployed by the company to build closer ties with political circles are therefore very clear. The decision to invest in the project to renovate an old district, with all the social problems this would involve, is part of the same intention: to win the favour of the government and the population so as to acquire a political capital sufficient to support economic activities.

However, unlike public companies, private companies are positioned outside the circles of political power. Their relationships with the government are fluid and unstable and enjoy no exclusivity. When there is a political transition, private companies are at the greatest risk because they cannot make direct use of public resources. Faced with the instability of these connections, private companies need to constantly reinforce their alliance with the various levels of government and demonstrate great resourcefulness to prevent being eliminated from the market.

\section{The relocation management centre}

The relocation management centre (dongqian zhihui bu 动迁指挥部) is a temporary organisation set up by and acting in the name of the District government. It is responsible for presiding over the work of coordinating between the District, the developer, and the relocation company for the duration of the process of moving the local population. It transmits official policies and directives to the relocation company. Although it does not participate directly in the relocation process, it does help draw up the adopted measures and cooperates with the developer, for example by setting the maximum amount of compensation offered to the residents.

As soon as problems emerge in negotiations with the residents, the management centre will convene a meeting of the representatives of the developer, the relocation company, and the Residents' Committees in question. Information concerning the official measures governing the relocation or the dwellings earmarked for rehousing is communicated by this organisation; similarly, the main meetings exhorting the various groups to leave their homes take place in the buildings that it occupies. The relocation management centre of the Old City of Shanghai is located, for example, in the premises of an old collective factory. Its personnel come from various departments of the District government. Their salaries are paid partly by their original work units, the remainder coming from subsidies paid by the developers to the management centre. Operating expenses are deducted from the management fees paid by the developers.

Mr. Li, my contact at the management centre for the Gujia Lu project, was not able to attend the university for "workers, peasants and soldiers" when he was young because his family had the wrong "political orientation." Through a random process, he ended up in the relocation sector after managing a municipal bus driver team. In 1995, work on Fuyou Street in the Old City resulted in a demand for new staff to complete the relocation work, and he offered his services on the recommendation of a close relation. Since then, he has constantly been working on relocation projects in the Old City. He explains how "The workers carrying out the first phase (i.e. the relocation phase) in projects to renovate old districts are the ones who suffer the most, because they have to deal directly with the population. The building and selling steps that follow are much more straightforward. However, although relocation is the first step of the project, the relocation workers have already moved on to other areas by the time the benefits start to show. They always remain in the dark."

Mr. Li concludes from his experience that during the work on Fuyou Street in 1995, the problem of relocation was easier to deal with than it is today because the gap between rich and poor was less pronounced and because the occupants had lower demands when it came to their relocation. Another major institutional reason is, he believes, the increasing recourse to financial compensation, a policy that has been advocated over the last decade. At the time of the work on Fuyou Street, the occupants were allocated a new home by way of compensation. He therefore feels that the introduction of financial compensation has resulted in a kind of endless bargaining that did not previously take place. ${ }^{(9)}$

\section{The relocation company}

The relocation company (dongqian gongsi 动迁公司) is one of the most specific actors in the system of urban renovation in China.

"Relocation company" is a familiar term used to describe a "relocation work unit that has obtained the certificate of qualification for relocation and demolition. It accepts the assignment from the demolition contractor (the developer), mobilises those who need to be moved within the framework provided, organises the signing of the compensation agreement, and makes the payment of compensation depending on the agreement reached" (Relocation management methodology of the city of Shanghai, January 2002, article 3).

The relocation company is therefore commissioned by the developer to negotiate with the occupants until their home is demolished. ${ }^{(10)}$ It is this company that conducts the negotiations with households (even though they actually sign a relocation agreement with the developer) after they indicate their choice of being rehoused or being paid compensation. The overriding principle is that negotiations are held household by household, and are confidential.

9. Interviews with Mr. Li, my contact for the Gujia Lu project in the Bureau of Relocation Mediation in the Old City, 23 January 2006 and 18 March 2007.

10. Once a relocation agreement has been signed between the developer and the family that is to be relocated, the work of the relocation company is complete. The relocation company will then assign a demolition team to destroy the building once the occupants have moved. The workers on the demolition are for the most part made up of migrants. 
The relocation company is selected following a public call for tenders. The developer sets the maximum cost of the relocation process, below which the relocation company enjoys freedom of negotiation, although it is expected to comply with the least-cost principle. The developer therefore does not have a direct hand in the process, unless negotiations with the occupants arrive at a total higher than the set amount, in which case the relocation company asks for advice from the developer and the final cost of the relocation may, if necessary, be jointly revised.

When a "relocation unit" is created, it must satisfy the following conditions (Relocation management methodology of the city of Shanghai, January 2002, article 4):

- It must be created with the agreement of the local administrative authorities;

- It must have a name, a specific organisation, a clearly specified sector of activity, and a fixed office address;

- The registered capital must be no less than RMB 10 million (RMB 5 million in the outlying districts), and that of a relocation unit with mixed activities can be no less than RMB 50 million (20 million in the urban districts);

- It must have at least three management positions in the areas of technology, finance, and financial management, and these must be filled by people with the relevant professional qualifications; - Its workforce must include at least 30 workers holding the "relocation workers' certificate of the city of Shanghai" (11) (a minimum of ten in the outlying districts);

- It cannot accept contributions of personal funds.

The relocation company is therefore independent, but the relevant higher authorities must approve its creation. Furthermore, "it cannot accept contributions of personal funds." Finally, "the relocation unit carries out relocations by delegation and deducts fees in exchange for the services procured, but making profit is not one of its aims" (Relocation management methodology of the city of Shanghai, January 2002, article 3). The relocation company is therefore a very specific establishment, both supported and controlled by the administration.

During the first phase of renovation of the old districts of Shanghai in the 1990s, the government drew up the renovation plan, carried out the relocation, and organised the construction projects. Its departments were therefore directly responsible for the relocation work. Today, a specialised company, apparently independent of the local government, carries out this work, but the occupants still feel that this crucial step is orchestrated by the local authorities and takes place in a government context. The relocation company is, in fact, a product of the various departments of the District that were involved in the construction and distribution of public housing before the housing system reform; it is linked to the District and city governments by myriad invisible connections.

These companies only have a small number of permanent staff who occupy key positions such as company director, relocation project manager, and financial director. They generally come from the bodies in the government property department that set up the relocation companies. Conversely, the employees who are effectively responsible for relocations and who negotiate with the occupants are all recruited on a temporary basis. They hold the professional certificate required for this work and move between various relocation companies. Their pay consists of a basic salary and a share in the profits. The director of one relocation company describes the skills of these relocation workers as follows: "Relocation work is not actually something that can be learned. Some people are just made for it. They know how to say the right things, and they can act flexibly. The official measures are fixed, so what matters is the experience that these senior workers have acquired." As Mr. Li from the relocation management centre of the Old City explains, "Relocation company agents cannot visit the homes of occupants on their own; there must be two of them. That's the rule. Two people work together, and each two-person team deals with moving 15 to 20 families. For example, if the relocation company undertakes to move 500 households, it will need 25 two-person teams to be on the job at the same time. Bit by bit, the number of households to be moved decreases, which means the number of agents also needs to be reduced by keeping only the most skilled on board. The others will go to other relocation companies. During a relocation process, the working day starts at 11 in the morning and ends at 8 or 9 at night. The employees are mobilised in door-to-door operations. Before 11 in the morning, the occupants have either not yet gotten up or have already left, so it makes sense to avoid those times. However, they will probably be at home after dinner." (12)

In the absence of a stable and consistent system of criteria to set the compensation amount, negotiating with the occupants is the most important part of the relocation process. The Xiangyuan Lu and Gujia Lu areas are two major projects affecting thousands of occupants, and the relocation process was therefore jointly entrusted to 11 relocation companies who shared offices in a temporary building with the relocation management centre. It should be noted that it was no easy task for the latter to coordinate the activities of 11 companies, but as time went by, the number of relocation companies declined. In January 2006, during my assignment within the Zhaofang Residents' Committee, there were still six relocation companies in the Gujia Lu area. ${ }^{(13)}$

Today, in the context of a slowing property market in the Shanghai city centre, there has been an appreciable reduction in the amount of business available to relocation companies. Therefore, in order to win market share or demonstrate their ability in relocation projects, relocation companies sometimes bring in their own capital to increase the compensation funds available to the developers, join the developers in assuming the various risks linked to the relocation process, and recover any unused funds when the relocation is complete. Even though the relocation process is a result of the contract signed between the relocation company and the developer in the framework of a call for tenders, in reality, relocation missions are the responsibility of a few companies that maintain relations with the governments of the Districts in question. Such a situation reinforces occupants' perception of a coalition between the relocation companies and the local government, and it reinforces the "official" nature of the relocation.

\section{The Residents' Committee}

The Residents' Committee or jumin weiyuanhui or juweihui (居委会) plays an extremely important role in the observed processes. Without its inter-

\footnotetext{
11. The "relocation workers' certificate of the city of Shanghai" is issued by the Municipal Property and Real Estate Management Bureau, the aim being to standardise relocation work. It has existed in Shanghai since 1994. Obtaining this certificate requires taking a competitive examination organised by the District Property and Real Estate Management Bureau following a two-week training course.

12. Interview with Mr. Li, 12 February 2006.

13. Author's notebook, 20 January 2006.
} 
vention, the relocation of thousands of families - as in the case of the Xiangyuan Lu project - would not be possible.

The "Residents' Committee" is officially an independent organisation established in 1952, three years after the People's Republic of China was founded. However, given the position it occupies and the role it plays, it amounts to far more than a mere civil authority. Indeed, the committee plays the role of intermediary between the government and residents. For the government, it represents a very important tool to manage and control society. For the residents, it is an organisation that is required to provide community services and represent the public interest.

Although it does not hold any official administrative power, the committee is, in Shanghai as in other Chinese cities, well integrated into the government management system denoted by the following description: "two-tier government, three-tier administration, four-tier network" (14) (liangji zhengfu 两级政府, sanji guanli 三级管理, siji wangluo 四级网络). It occupies the lowest position of a four-tier hierarchy, the first three of which are the municipal government, the District government, and the Subdistrict Office (jiedao banshichu 街道办事处). Its staff and activities are under the authority of the latter body. Officially, it has six privileged areas of action: managing the population, public services, people's mediation, security, supporting government action, and expressing the opinions of the people. However, in practice, the committee's work goes far beyond this remit, and also includes maintaining public spaces, hygiene, civil security, helping the poor, birth control, and managing the migrant population. As the committee has become, to all intents and purposes, the assistant of the Subdistrict Office, government departments see it as an organisation at their service and assign all kinds of administrative tasks to it.

During the negotiation phase, the cooperation of the Subdistrict Offices and Residents' Committees is indispensable. Their members have an indepth knowledge of the households they administer. Without the support they bring to the relocation company, negotiations would be difficult to conduct. In the case of renovation projects in the Old City of Shanghai, the District government quite simply and officially requests that the Bureaus and committees support the relocation process.

However, the Residents' Committee has a delicate role to play when relocating households. On the one hand, the people who work there are responsible for complying with the directives issued by the District government and encouraging negotiations between the residents and the relocation company; on the other hand, as occupants of the district, they are just as affected by the relocation operations as their neighbours are. Moreover, those who live around them think that their position within the administrative hierarchy gives them access to internal information about the relocation. They also believe that the committee helps the relocation company to assess the amount of compensation, and also that it has a say in the negotiation process. They therefore try to curry favour with committee members. Yet the committee is only partially aware of the measures that are taken: the developers need the committee in order to be kept informed about the households and to establish contact with them, but they do not want to disclose too much information to it, precisely because of its proximity to the occupants.

Over the course of the relocation process, the Residents' Committee must continue to perform all the other tasks for which it is responsible. It must wait until the last family has left the district before it can be dissolved, because it has to ensure security until the end of the relocation, a process that often gives rise to intense conflict. In the Gujia Lu district, a lack of capital led to the project being interrupted. Even though 800 families had already been moved, they were widely distributed over the built area. This meant that in a given building, recently emptied apartments were interspersed with others that were still occupied. As it was impossible to proceed with the demolition, the empty housing very soon became a source of insecurity. Therefore, shortly before the Spring Festival in 2006, the biggest concern of the Residents' Committee was to prevent fires breaking out, because this could prove disastrous in a district of old, timber-framed houses. To prevent lawbreakers from getting into the empty apartments and setting them on fire, the committee sealed the doors and windows with bricks. As one member of the Residents' Committee explains, "It makes more sense to move all the families out of one building and then demolish it to eliminate this latent uncertainty. It has become more difficult to maintain security in the community because some families have been moved out but others still remain." (15) If we add to this the accidents caused by electrical overloads, disputes between neighbours, and all kinds of tensions, the problems caused by stopping the relocation, in this particular case, considerably increased the difficulty and the quantity of work to be carried out by the Residents' Committee.

\section{The displaced occupants}

In China, displaced persons (bei dongqian ren 被动迁人) and those who are rehoused or compensated in case of relocation - all are considered part of the same group - are identified by their residence permit or hukou. According to the "Regulation on the identification criteria of occupants to be rehoused in Shanghai" (2006), "occupants to be rehoused" (anzhi renkou 安置人口) are those who "until the day on which the demolition permit is issued for the housing in question, live in this housing, have possessed, for more than a year, a residence permit for the address of this housing, and do not have any other housing in the same city (or do possess other housing but are unable to move there)." Individuals who do not have a residence permit for the address of the housing that is to be demolished are considered occupants to be rehoused if, and only if, they are married to someone who belongs to the category of occupants to be rehoused or compensated, and have lived in this housing for the two years prior to the date on which the demolition permit is issued.

Holding a residence permit for the address of the housing to be demolished is therefore the first condition for qualifying for compensation or rehousing. However, many occupants in the districts in question are not official residents there. Their residence permit may be registered elsewhere, while some live elsewhere but are registered as occupants of the district. In other words, there is a discrepancy between official and actual residence. Most of the occupants holding residence permits in the two districts observed were people who had inherited the right of use of public housing and who sub-let their home to new tenants coming from other districts in the city or other regions of China.

Therefore, the occupants who are authorised to negotiate with the relocation company are not always those who come up against the biggest housing problems. Also, the city residence permit is known to be associated with a whole series of social benefits relating to health, education, and unemploy-

14. Lin Li, Xiandaihua guocheng zhong de chengshi guihua maodun jiqi zhili, yi Shanghaishi jiejue chengshi guihua wenti weili (Solving development problems during urban modernisation, the Shanghai case), Masters dissertation, Shanghai, Fudan University, 2005.

15. Author's notebook, 13 January 2006. 


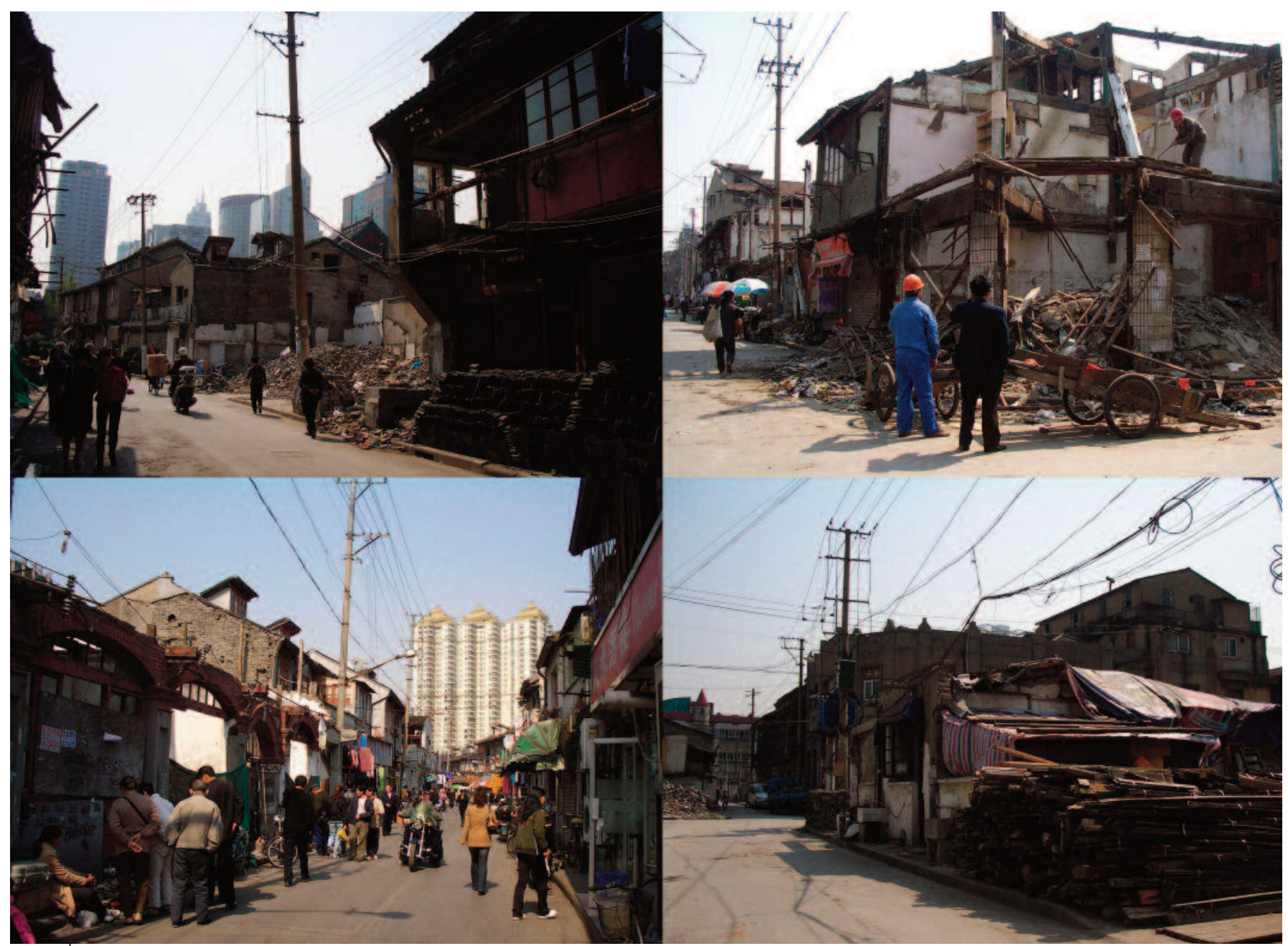

Fanbang Zhonglu during the relocation ๑ Zhang Kai

ment benefits, which explains why so many people try to register their permit in an urban location. These benefits also differ from district to district within a given city, and are often more generous in the city centre districts, hence the strategies deployed by households to have their permit moved to these districts. This helps explain the choice taken by families who are originally from the oldest districts of Shanghai (which are also the most central) to keep their residence permit registered there, even if they actually live elsewhere, while they wait, in particular, for a renovation project to be announced.

It might therefore appear to be the case that once the land use contract has been signed, the District government is consigned to the background, and negotiations are conducted between the property developers and displaced occupants. However, the reality is quite different. Where the District government would previously have acted alone, a large number of institutions are now active. Each of them is, in a manner of speaking, influenced by the official sphere without actually being officially controlled by it. However, the nature of this influence varies in each case.

We have already looked at the structural links established between local governments and public developers, but a very particular alliance and interdependence also exists between these local authorities and private developers. The former depend on the latter to complete some of their operations, while the latter depend on the former to develop their economic activities. The function of the relocation management centre, a temporary authority directly overseen by the District government, is to coordinate - and supervise - the actions of the government, developers, and relocation companies involved in a given renovation project. It is in the buildings they occupy that disputes are settled and solutions are proposed for any difficulties that are encountered. As far as the relocation company is concerned, its very existence must be approved by the local administration, and its personnel come from various departments of the District and the city. Finally, the Residents' Committees, which are officially independent organisations, actually make up the fourth tier of the urban administration, and are issued with an order to support the relocation.

Therefore, although the relationships may be direct or indirect, and more or less official and explicit, these organisations do lie within the official sphere. However, they do not lie only within this sphere, enabling the public assertion that the District government is not carrying out the relocation process itself or by delegation. Such a situation deserves a more thorough analysis to show how the sphere of power and the social, or civil, sphere are entangled, whether directly or indirectly, institutionally or not, and in theory or in practice. This enables a particularly effective exercise of power as well as ambiguity and therefore uncertainty as to the categories, principles, and standards to be mobilised depending on the situation.

Although they may never come into direct contact with representatives of the city and District government, occupants set for removal are not mis- 
taken in their belief that these projects not only issue from an official decision but are also overseen from start to finish by the local authorities. Their response to projects that are underway is coloured by this understanding. It is also coloured by the many actors - whose responsibilities and obligations are only vaguely defined - with whom they have to deal directly and who are never, for that very reason, official representatives of the District government. Finally, it is directly influenced by the rules of the game that apply when carrying out an official project of this kind. The most important of these rules consists in resorting to personalised, confidential negotiations, which have no protective system of stable rules and measures, between the relocation company and households.

\section{The response of the relocated occupants}

The households affected by a renovation project will have generally lived through differing experiences; they do not all share the same situation, and they pursue different goals. In particular, they do not all share the same situation in terms of the first official criteria, the address at which their residence permit is registered. The occupants of the old districts that were observed can effectively be split into two institutional categories: occupants living at their official registered address, and migrant populations. The migrant populations are excluded from the "occupants to be rehoused" category.

Within the first category, I saw three attitudes displayed with regard to relocation. This diversity results directly from the importance assigned to having one's official registered address, rather than actual address, in the district set aside for renovation.

Some residents are satisfied with their current living conditions, are attached to their environment and home, and do not wish to move. They would like the building in which they live to be added to the list of protected buildings, as this would make it possible to challenge the relocation, and should it still go ahead, they would receive better compensation.

Other occupants are not satisfied with their current housing conditions but do not have the economic ability to improve them. They would like the developers to intervene as quickly as possible in order to use the compensation to acquire new apartments. Some of the members of this group have lived in the district for a long time and also feel an attachment to it, but their desire to improve the living conditions of their family prevails. They are therefore not interested in questions about the future of the district and the destruction of old buildings. This was the largest group in the districts I observed. It should be noted that in old districts such as those found in the Old City, where many families live on modest incomes, a common saying is: "The poor get rich through relocation" (qiongren fanshen kao dongqian 穷人翻身靠动迁). This reflects the fact that often the only way for families living on a modest income to improve their living conditions is to take advantage of a renovation project. As the majority of the homes used to rehouse occupants are located in the distant outskirts, most households decide to opt for financial compensation. They then buy a second-hand apartment in the city centre or two apartments in the outskirts, depending on the size and make-up of the family.

Finally, there is a third group made up of people who are not experiencing particular hardship and actually enjoy fairly comfortable living standards. Most of them have moved away but have kept their residence permit at their old address. They are no longer especially attached to the district, and view the relocation process as nothing more than a way of making money.
In other words, most of the occupants I met during my investigation approve of the renovation project that is underway. Regardless of the amount of compensation paid, they see it as a unique opportunity to improve the housing conditions of their family. For example, on the top floor of No. 61 Jinjia Fang Street, four members of the same family were sharing a $20 \mathrm{sq}$ metre apartment divided into two rooms, a living room, and a loft: the grandmother, her son, daughter-in-law, and grandson, a student at Songjiang University who only came home on weekends. The grandmother told me: "Of course I would like to stay here. It's a convenient place to live, the neighbours are nice and it is safe. If we move, each family will make its own choice, and we will no longer be together. I am not for the move. I am used to living in this peaceful neighbourhood, my pension is enough to pay the rent, and there are none of the monthly service fees that are charged in the new complexes. Nevertheless, my son and his wife would like to live in a new apartment." (16)

In a residence near Jinjia Fang Street that is going to be restored, Mrs. Zhang told the assembled group, "Take more photos now, because there won't be anything left here soon. This building might look like it is in a better state now, after restoration, but it is actually in a very bad state. It was built 70 or 80 years ago. We all get on, everyone in the building, but I cannot afford to live anywhere else... And let's not delude ourselves about the fact that it will be too expensive for us to come back and live in the district. In spite of everything, I am not going to be one of the first to move; I'll be living in a 'nail house' [dingzi hu 钉子户]." (17)

As we have already seen, negotiations between the relocation company and each occupant take place confidentially, with the content of the negotiation kept secret. This process fuels divisions and suspicions. On the one hand, the occupants would like to know the progress of negotiations between the company and their neighbours, in order to make sure they are not losing out; on the other hand, they do not intend to disclose the details of their own situation. Generally, those who have set their sights on new housing do not want negotiations to become too drawn out, for fear that the whole operation will be brought to a standstill. Indeed, if the project is suspended, as happened in the Gujia Lu project, the relocation, along with all the promises that went with it, is postponed for an indeterminate period. At the same time, the longer they wait, the higher the compensation will be, which explains why none of them wishes to see their neighbours obtaining better compensation than they do. Their strategy is therefore complex. On the opposite side of the equation are those occupants who have already purchased an apartment elsewhere. They are expecting only to receive compensation for the relocation, and have no qualms about delaying the negotiation in order to maximise their profit. They have nothing to lose, because if the relocation programme is stopped, this will not have a fundamental impact on their situation.

As a result of the confidential nature of the discussions, which can also result in widely varied compensation amounts, and because of the many situations and strategies of the residents, it is not easy to organise collective negotiations. When the occupants come up against the relocation company, they struggle to present a united front. They often lack the ar-

16. Notes from an interview with occupants, 11 January 2006

17. Notes from an interview with occupants, 7 January 2006. The houses occupied by households who refuse to leave and are the last to remain on the property when their old neighbours have moved out are referred to as "nail houses" by the government. These buildings remain dotted here and there, surrounded by flattened dwellings, and can only be "removed" by forcing the households in question to leave. 
guments and motivation needed to defend their situation in the face of a project that they view as official. Also, they find themselves in a situation that is both blurred and multi-faceted, yet in which they can nevertheless discern the political and economic issues involved. Finally, the fact that the negotiations are not conducted directly with the main actors in the relocation process, the District government or the developer, does not make it any easier to foster forms of collective mobilisation. The residents therefore have the feeling that they are better placed to protect their personal interests if they act alone. The relocation companies are capable of exploiting this situation to their advantage, provoking tensions between them. One way in which the companies do this, for example, is by breaking off all negotiations in a building in which there are both households pushing for a swift agreement and "nail households" who will grab at any opportunity to postpone the agreement for as long as possible. This interruption usually leads to tensions between neighbours as it diverts their attention to each other.

Insofar as relocation represents the best, or indeed only, opportunity for certain households to acquire housing, and faced with the flawed and random nature of the compensation system, occupants seek to maximise their interests. One of the most widespread ways of doing so is to increase the number of members of the household who have residence permits registered in the district. Consequently, after the relocation process in the Gujia Lu district was interrupted in 2005 , the number of new residence permits registered in 2006 was higher than over the two years previous to that. "Even though residence permits do not count if they are registered after the demolition permit is issued, it is always better to have a high number of hukou in the household. Another way of doing this is to include the names of two members of the household on the tenancy documents," said one member of the Residents' Committee. ${ }^{(18)}$ In this way, the object of the negotiation is increased to two households. If it is not possible to increase the number of residence permits, this is the best way of obtaining a bigger floor area or more compensation.

It should be emphasised that the situation I observed in these two neighbourhoods in the Old City was particularly complex. The names of people since deceased were still included as members of the household on tenancy agreements that had not been revised for around ten years. This applied to half of the 800 families relocated from the Gujia Lu district. Since having an additional hukou strengthens the position of a household when it comes to negotiating with the relocation company, these deaths were not always brought to light at the time of the relocation, but were instead indicated when the new property certificates accompanying the rehousing process were drawn up. For this reason, Mrs. Yang, who was responsible for providing the new property certificates for the Zheshang company, for a long believed that the moves were injurious to the health of old people, until she realised that the occupants were simply not indicating changes that had taken place in the make-up of the household, and were instead presenting documents that were rarely updated.

Apart from these very widespread strategies, other means are also used in attempts to make the most of relocation, such as marriages of convenience or false divorces. ${ }^{(19)}$ For example, a family of three (two parents and one child) officially living in housing earmarked for destruction can, in theory, obtain an apartment consisting of two bedrooms and a living room. However, if the child has already applied for a marriage certificate, two generations need to be rehoused, and the developer must offer two apartments, each consisting of a living room and a bedroom.
While certain processes might appear to be somewhat immoral, director $\mathrm{Xu}$, who is managing the relocation process in the Xiangyuan Lu project, points out, "Public opinion always protects the occupants, even if people like us, who are working on the front line, know full well that in order to protect their interests as completely as possible, residents can disregard any moral code. Therefore, many people marry and then file for divorce as soon as the demolition permit has been granted. At present, the biggest problem with the relocation process is still the ambiguity of the rules of the game. The occupants can resort to various means to increase their gains, but the same applies to us [the developers]. The existing government advocates the idea of a 'harmonious society' [hexie shehui 和谐社会] and is fearful of occupants complaining to the higher authorities. As a result, the local government brings this pressure to bear on the developers, while public opinion generally sides with the occupants. We are a public company, and we have to complete this project without conflicts; this is particularly difficult." (20)

The situation is even more complex because the ambiguous compensation system allows regular increases in the compensation amounts over the course of negotiations. This means that the longer the relocation is delayed, the greater the advantages for occupants. As a result, the families who move out last obtain the highest compensation. Mrs. Yang, who is in charge of registering the new property certificates, has seen all the relocation agreements of the occupants, and knows the amounts in question: "I would never have thought there could be such large differences between the compensation amounts in a given relocation project. Some occupants give up very quickly. But are they actually losing out simply because they do not know how to argue, or cannot find the right arguments in the negotiation process?" (21) The lack of legal mechanisms explains these fluctuations. "Here [Gujia Lu district] they were offering RMB 150,000 per household at the start of the relocation process in 2003. That was enough money at that time to buy a two-room apartment. Today, it would only buy you a corner of one room. What will occupants who have not bought an apartment in time do? Hopefully, the government will solve their housing problem one day. In every renovation project in an old district, there are a few families who come up against difficulties like this. There are not many of them, but the sum of these small numbers adds up to a significant total. Last year [2005], 60 people were sleeping in Huaihai Park as a result of finding themselves in this predicament. They had not bought an apartment in time with their compensation, and were now unable to buy one," explains a member of the Residents' Committee. (22)

In the Xiangyuan Lu district, 4,000 families were relocated between 2003 and 2007. "In the end, the compensation amount was approximately RMB 1,700,000 per household compared to the RMB 160,000 it had been in 2003. The compensation amount received by the last families was very high, but I am not able to give you the figure. Relocation rules absolutely must be drawn up, because the families who refuse to move out harm the interests of the other occupants who have already moved out. Therefore, it

18. Author's notebook, 22 January 2006.

19. A three-person family might, for example, be rehoused in a three-room apartment. If there is a divorce, two families then need to be rehoused. The same family can then easily obtain two apartments, each consisting of two rooms.

20. Interview with $\mathrm{Mr}$. Xu, relocation manager of the Xiangyuan Lu project for the Fuyue company, 11 October 2007.

21. The author's notebook, 21 January 2006.

22. Interview with Mrs. Du, director of the Zhaofang Residents' Committee, 17 January 2006 


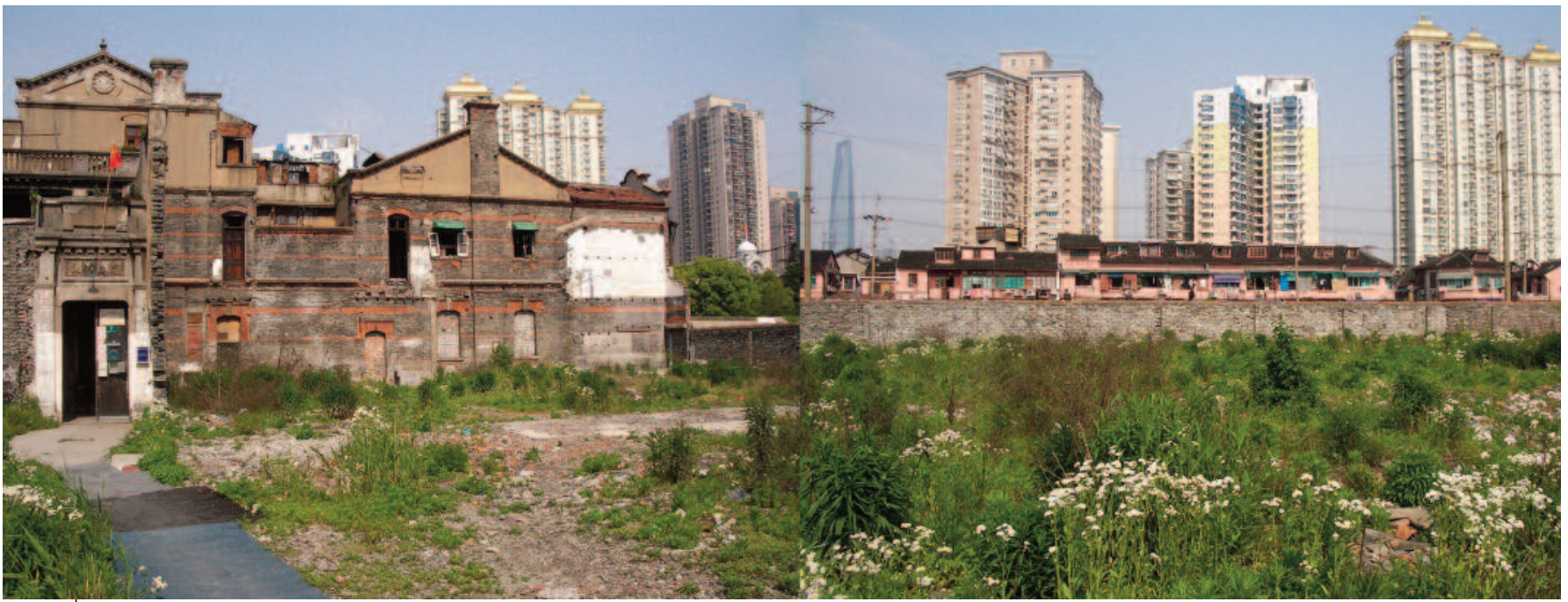

Xiangyuan Lu in 2008, after the relocation process ๑ Zhang Kai

is a question of social justice," explains director Xu, referring to the situation observed during the last relocation phase of the Xiangyuan Lu area. (23)

\section{Conclusion}

One of the factors explaining the discord and tensions that go hand in hand with the relocation processes is therefore the lack of clarity in the officially established rules, whether those issued by the official institutions and concerning measures that are supposed to govern the relocation process, or the actual practices adopted to complete this process. Consequently, the situations observed are open to interpretations and reactions that are both varied and variable: a project like the renovation of the old districts of Shanghai becomes laden with a great variety of aims and strategies that are not governed by a common framework and which give rise to all kinds of discontent and feelings of injustice. During the course of my investigation, I was able to measure the costs of such a situation and became aware that actors as varied as households to be relocated, the relocation company, and the developer all wanted a transparent and consistent system of rules and directives to be adopted.

Indeed, even though the local, District, and city governments do not invest public money, and no longer carry out relocation themselves, they do control and supervise such processes, and therefore have an obligation to set up a system that protects the interests of both the households to be relocated and the developers. As far as the former group is concerned, transparent and non-adjustable compensation and rehousing criteria that are not dependent on endless interpersonal negotiations would help reduce tensions and dissatisfaction. As far as the latter group is concerned, there is a need for shared rules enabling them to forecast, as rationally as possible, the risks and profits offered by a project so they can make an informed decision whether or not to become involved.

The reason why such a system has yet to see the light of day is that, paradoxically, the transformation of the old districts of the city, despite being the result of official intention, has not yet been officially recognised as a "common," "collective," or "public interest" project, whatever the precise wording one wishes to use. Interpreting it as such would make it possible to prioritise expectations and set out standards with which to comply. On the contrary, this transformation is currently based on varying alliances established in a manner specific to each operation between the local governments and the private or public developers chosen to complete the task. As we have seen, this process enables the city and district authorities to resort to external capital and avoid a showdown with society and all the unknown factors this would involve.

Local governments are therefore the nerve centres of relocation processes, and their links with the developers play a decisive role; the relocation management centre, the relocation company, and the Residents' Committees all lack real authority and do nothing more than support their aims. The occupants are rendered powerless, and occupy the position assigned to them in such a situation. Many residents are housed in dark, cramped, unhealthy apartments, and relocation is seen as a blessing. The reason they adopt a hostile attitude towards it is often because they are not satisfied with the rehousing or compensation offers made to them, rather than being unhappy with the idea of relocation in itself. In order to understand their expectations, their paths in life need to be placed in historical context: during a relocation process, the specific statuses of certain households to be relocated are not clear, for example heads of family who were previously employed by work units (danwei), (24) "educated urban youths" sent to the countryside before returning to the city ten or 20 years later with no possibility of accessing housing, and senior employees who have been pensioned off or made redundant. In such cases it is not simply a question of housing but a problem of defining the social benefits that go hand-in-hand with the status of these categories of the population. The allocation of very low rent housing used to be one of these benefits. After the reforms, some of these benefits remained, for example the right to use public housing, or the purchase of housing at a low price. But some categories of the population, such as former "urban educated youths," are excluded from the housing allocation

23. Interview with $\mathrm{Mr}$. Xu, relocation manager of the Xiangyuan Lu project for the Fuyue company, 11 October 2007. The amount paid for relocations therefore increased tenfold, while the average price of property increased twofold in Shanghai during the four-year relocation period that was observed (2003-2007). Therefore the compensation amounts and the price of housing are not changing in tandem with one another. The swifter increase in the compensation amounts are taking place against a backdrop of increasing social criticism aimed at the forms of relocation and also of a lack of clear criteria upon which relocation compensation is based.

24. The work units used to be responsible for distributing housing to their employees. 
process and, owing to a lack of resources, have been unable to purchase their housing at a price negotiated with their work unit and gain access to the property market in this way. A relocation operation therefore represents their last chance of being allocated housing. From their perspective, there is a continuity between the policy of work units allocating housing to employees and the housing acquired in a relocation process. Also, the compensation amount does not depend only on the price reached on the property market: it must also reflect the benefits they are due and which they have been denied for decades. ${ }^{25)}$

Insofar as relocation processes are considered to originate with the District and city government, they are associated with official promises that have been made and with the resulting disappointed expectations. They must allow for justice to be restored - in light of the time frame involved, which cannot be reduced to the immediate present concerned by the relocation process - in order to provide an opportunity of property ownership to people who previously lacked the means. Hence the complexity of the feelings of justice or injustice - and, therefore, of the demands tabled.

Since 1991, successive renovation projects have resulted in the relocation of approximately one million households in Shanghai, accounting for a quarter of the residents having their official home in the city. Only a minority of them held property rights to the apartment in which they lived before being relocated. For example, only 20 of the 1,800 households administered by the Zhaofang Residents' Committee owned their property. Successive relocations have therefore not only improved the living conditions of a quar- ter of the families in the city, they have also enabled them to become property owners. Regardless of the tensions that have accompanied these processes, this result cannot be contested.

Despite the many instances of dissatisfaction, it appears that the differing interests of the various actors referred to in this article have been relatively well protected during these relocation processes. However, this acknowledgement only stands up if we take only economic and material questions into account.

In reality, the social cost of these relocations is immense. In order to allow the developers to generate profits, local governments have given them the right to move the population from the districts in question and to build luxurious, expensive residences in place of the old housing. The old occupants of these districts may have become property owners, but the property they own is in outlying areas, while the districts closer to the city centre undergo a gentrification process and are increasingly home to people arriving from other cities and provinces. The property heritage of the old districts has been lost, the previous occupants evicted, and the foundations that allowed the city to come into existence, grow, and renew itself have gone.

\section{Translated by Will Thornelly.}

I Zhang Kai is a town planner at the Shanghai Tongji Urban Planning \& Design Institute, 1239 Siping Road, Shanghai, China (k_chang@hotmail.com).
25. Chen Yingfang, "Chengshi kaifa de zhengdangxing weiji yu helixing kongjian" (The crisis of justice and the space for rationality in urban development), Shehuixue yanjiu (Sociological research), No. 3, 2008, pp. 32-39. 